\title{
Range extension of Boeckella bergi Richard, 1897 (Crustacea: Copepoda: Centropagidae), with comments on the taxonomy of the species.
}

\author{
Daniel Previattelli ${ }^{1,4}$, Gilmar Perbiche-Neves ${ }^{2}$, Silvina Menu Marque ${ }^{3}$ \& Carlos Eduardo Falavigna da Rocha ${ }^{I}$ \\ ${ }^{1}$ Universidade de São Paulo, Instituto de Biociências, Departamento de Zoologia, São Paulo, SP, Brazil. \\ ${ }^{2}$ Universidade Estadual do Centro-Oeste, Departamento de Biologia, Campus CEDETEG, Guarapuava, \\ PR, Brazil. \\ ${ }^{3}$ Universidad de Buenos Aires, Facultad de Ciencias Exactas y Naturales, Departamento de Biodiversidad y \\ Biología Experimental, Buenos Aires, Argentina. \\ ${ }^{4}$ Corresponding author: Daniel Previattelli,e-mail: dpreviattelli@gmail.com
}

PREVIATTElli, D., PERBICHE-NEVES, G., MENU MARQUE, S., ROCHA, C.E.F. Range extension of Boeckella bergi Richard, 1897 (Crustacea: Copepoda: Centropagidae), with comments on the taxonomy of the species. Biota Neotropica. 15(3): e20140076. dx.doi.org/10.1590/1676-06032015007614

\begin{abstract}
We present new records of Boeckella bergi at several water bodies in Argentina and Brazil. Within these records the northernmost and southernmost limits of occurrence of $B$. bergi in South America are included. The ample range of distribution is consistent with former studies, but it is more extensive than previously known. Observations on habitat preferences are also made. This species is tolerant to temperate climate conditions in this region of South America, with wide amplitude of temperature between summer and winter seasons, and irregular patterns of precipitation.

Keywords: Biogeography, distribution range, freshwater, Copepoda, South America, zooplankton.
\end{abstract}

PREVIATTELli, D., PERBICHE-NEVES, G., MENU MARQUE, S., ROCHA, C.E.F. Extensão da faixa de ocorrência de Boeckella bergi Richard, 1897 (Crustacea: Copepoda: Centropagidae), com comentários sobre a taxonomia da espécie. Biota Neotropica. 15(3): e20140076. dx.doi.org/10.1590/1676-06032015007614

Resumo: No presente artigo são apresentados novos registros de Boeckella bergi em vários corpos de água na Argentina e no Brasil. Dentro desses registros estão incluídos os limites setentrionais e meridionais de ocorrência de $B$. bergi na América do Sul. A ampla gama de distribuição é consistente com estudos anteriores, mas se mostra muito mais extensa do que conhecida anteriormente. Observações sobre a taxonomia e os habitats também são feitas. Esta espécie é tolerante a condições de clima temperado na região da América do Sul, com uma grande amplitude de temperatura entre o verão e inverno, e padrões irregulares de precipitação.

Palavras-chave: Biogeografia, área de ocorrência, água doce, Copepoda, América do Sul, zooplancton.

\section{Introduction}

Boeckella Guerne \& Richard, 1889 is a copepod genus from the Centropagidae family, a group with gondwanic distribution (Boxshall \& Jaume 2000). The genus is composed of 41 species (Boxshall \& Halsey 2004), mainly restricted to the Southern Hemisphere. They are found in Australia, Tasmania, New Caledonia, New Zealand, Antarctica, circumantarctic islands and South America, all once belonging to the paleoantarctic fragment of Gondwana (Bayly 1992b).

The South American species of the genus Boeckella are endemic to this continent with exception of B. poppei (Mrázek 1901), which appears in the Malvinas Islands (Ekman 1905), several circumantarctic islands (Poppe \& Mrázek 1895; Ringuelet 1958; Pezzani-Hernández 1973; Weller 1977; Paggi 1983; Janiec 1988) and also in both East and West Antarctica (Ekman 1905; Harding 1941; Heywood 1977; Bayly \& Burton 1993). This distribution pattern would thus indicate a speciation process within the South American continent after the
Gondwana splitting. However, the comprehension of the taxa history and evolution becomes difficult, since species distributions are often incomplete and unclear, especially regarding the northern limits and scarcely sampled regions in Patagonia.

Species of Boeckella thrive in the Andean biogeographic region, and some are found in the South American transition zone (sensu Morrone 2004), with a few extending their distributions into the Neotropical region. The easternmost occurrences correspond to $B$. bergi, until now reaching as far as the southernmost region of Brazil, at Lagoa dos Patos (Gloeden 1994).

In this study new records of $B$. bergi in South America are given, extending its occurrence to north and the south of previous records.

\section{Material and Methods}

Samples were taken by horizontal hauling of a $60 \mu \mathrm{m}$ mesh size plankton net. Specimens were collected from 13 locations in Brazil and Argentina (Table 1 and Figure 1). Here we 
Table 1. New records of Boeckella bergi in Argentina and Brazil.

\begin{tabular}{|c|c|c|c|c|c|c|}
\hline & Locality & Province / State & Date & Latitude S & Longitude W & Museum number \\
\hline 1 & Dique Roggero & Buenos Aires & 28/11/1999 & $34^{\circ} 41^{\prime} 09.65^{\prime \prime}$ & $58^{\circ} 51^{\prime} 29.29^{\prime \prime}$ & MACN-In39443 \\
\hline 2 & Lago Pellegrini & Río Negro & $01 / 03 / 1984$ & $38^{\circ} 41^{\prime} 53.01^{\prime \prime}$ & $68^{\circ} 00^{\prime} 58.94^{\prime \prime}$ & MACN-In39444 \\
\hline 3 & Laguna de los Padres & Buenos Aires & $03 / 10 / 2004$ & $37^{\circ} 56^{\prime} 31.74^{\prime \prime}$ & $57^{\circ} 43^{\prime} 38.22^{\prime \prime}$ & MACN-In39445 \\
\hline 4 & Lagunita en Ao. Seco & Río Negro & $17 / 02 / 2004$ & $41^{\circ} 45^{\prime} 50.16^{\prime \prime}$ & $66^{\circ} 30^{\prime} 06.78^{\prime \prime}$ & MACN-In39446 \\
\hline 5 & Lagunita circular Ruta 3 & Santa Cruz & $20 / 012001$ & $49^{\circ} 43^{\prime} 34.33^{\prime \prime}$ & $68^{\circ} 21^{\prime} 46.71^{\prime \prime}$ & MACN-In39447 \\
\hline 6 & Pozón Río Deseado & Santa Cruz & $18 / 01 / 2001$ & $46^{\circ} 53^{\prime} 04.50^{\prime \prime}$ & $68^{\circ} 08^{\prime} 42.90^{\prime \prime}$ & MACN-In39448 \\
\hline 7 & Canterita anegada & Santa Cruz & $30 / 01 / 2001$ & $50^{\circ} 25^{\prime} 19.32^{\prime}$ & $72^{\circ} 40^{\prime} 47.70^{\prime \prime}$ & MACN-In39449 \\
\hline 8 & Charco en pasto anegado & Chubut & 03/02/2001 & $45^{\circ} 37^{\prime} 04.20^{\prime \prime}$ & $68^{\circ} 58^{\prime} 35.82^{\prime \prime}$ & MACN-In39450 \\
\hline 9 & Lago Pellegrini & Río Negro & $02 / 11 / 1996$ & $38^{\circ} 41^{\prime} 53.01^{\prime \prime}$ & $68^{\circ} 00^{\prime} 58.94^{\prime \prime}$ & MACN-In39451 \\
\hline 10 & Dique Ameghino & Chubut & $01 / 12 / 1984$ & $43^{\circ} 44^{\prime} 00^{\prime \prime}$ & $66^{\circ} 31^{\prime} 41^{\prime \prime}$ & MACN-In39452 \\
\hline 11 & Mallín Piedra Parada & Chubut & $15 / 11 / 2007$ & $42^{\circ} 38^{\prime} 09.0 \prime$ & $70^{\circ} 13^{\prime} 55.6^{\prime \prime}$ & MACN-In39516 \\
\hline 12 & Bom Jardim & Santa Catarina & $28 / 10 / 2012$ & $28^{\circ} 16^{\prime} 4.00^{\prime \prime}$ & $49^{\circ} 54^{\prime} 38.26^{\prime \prime}$ & MZUSP-30600 \\
\hline 13 & Roadside pool & Santa Catarina & $27 / 10 / 2012$ & $28^{\circ} 23^{\prime} 37.30^{\prime \prime}$ & 49³3'1.82”' & MZUSP-30601 \\
\hline
\end{tabular}

provide new records from Argentina in the provinces of Buenos Aires, Rio Negro, Chubut and Santa Cruz (Table 1 and Figure 1 left) and from Brazil in the state of Santa Catarina (Figure 1 right). They were found at two small water bodies at high altitudes - roadside pool near the city of São Joaquim, at $1350 \mathrm{~m}$ (Figure 1A) and a small pond near the city of Bom Jardim da Serra, at $1418 \mathrm{~m}$ (Figure 1B). Previous records were added from the revised literature (i.e. Mrázek 1901; Brian 1925; Pesta 1927; Richard 1897; Brehm 1935, 1936, 1937, 1954; Ringuelet 1958; Reid 1991; Gloeden 1994; Menu-Marque \& Locascio de Mitrovich 1998; Menu-Marque et al. 2000), and are shown in Figure 1.
Vouchers containing 13 individuals $(10$ males and 3 females) of B. bergi from Brazil were deposited at Museu de Zoologia da Universidade de Sao Paulo (MZUSP) and the specimens from Argentina at Colección Nacional de Invertebrados del Museo Argentino de Ciencias Naturales "Bernardino Rivadavia" - (MACN-In) (Table 1).

Images and scan photos were taken from animals collected in 2012 in Brazil (Table 1). Images were acquired with the aid of a Zeiss Discovery V-20 stereoscopic microscope, and the software Axio-Vision 6.0. Specimens of both sexes were prepared for scanning electron microscopy (SEM) following protocols used by Felgenhauer (1987) and Huys \& Boxshall (1991).

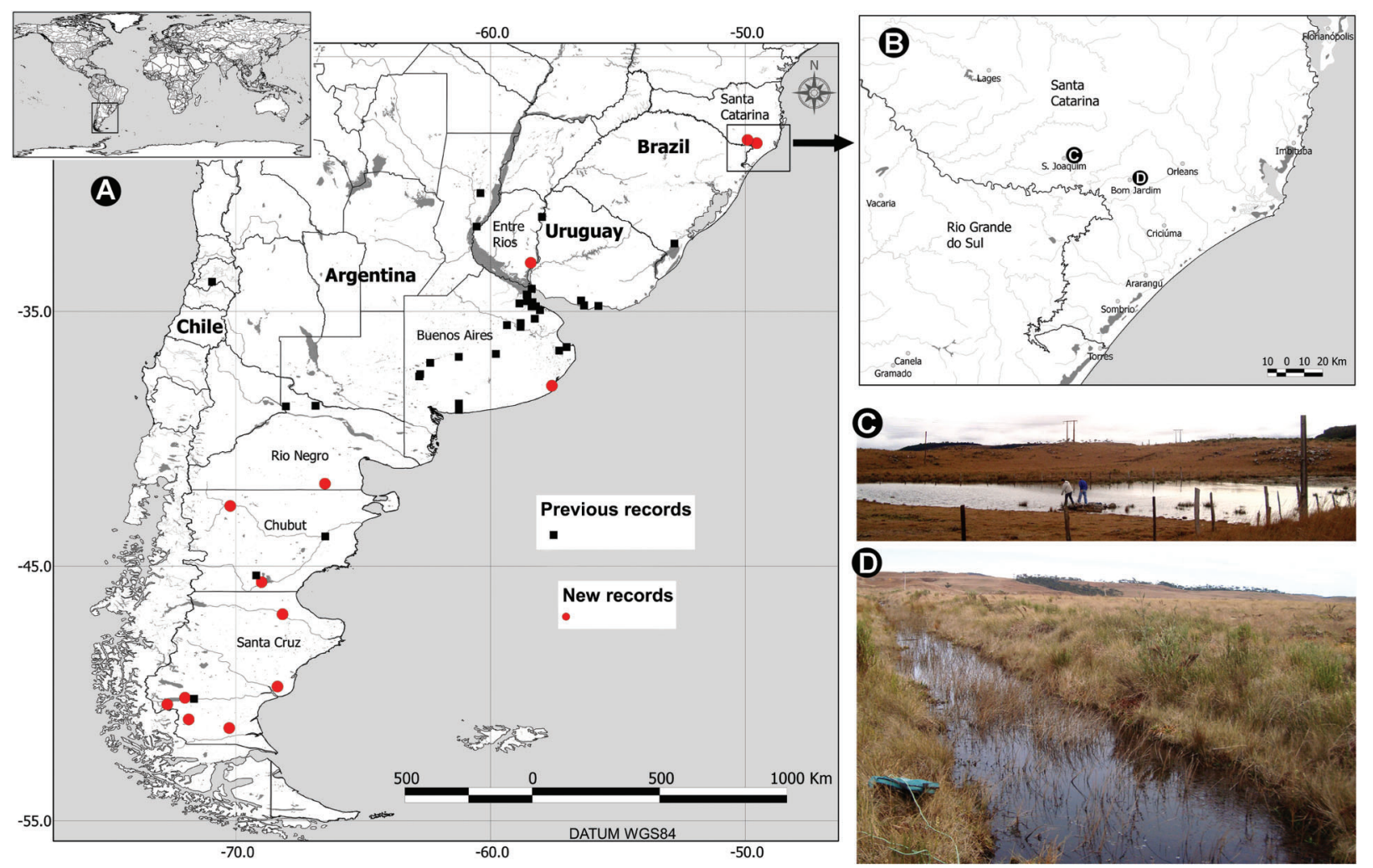

Figure 1. A. map of new and previous records of Boeckella bergi found in South America. B. New records of Boeckella bergi in Brazil, at pools of high altitude in São Joaquim (C) and Bom Jardim da Serra (D) localities. 


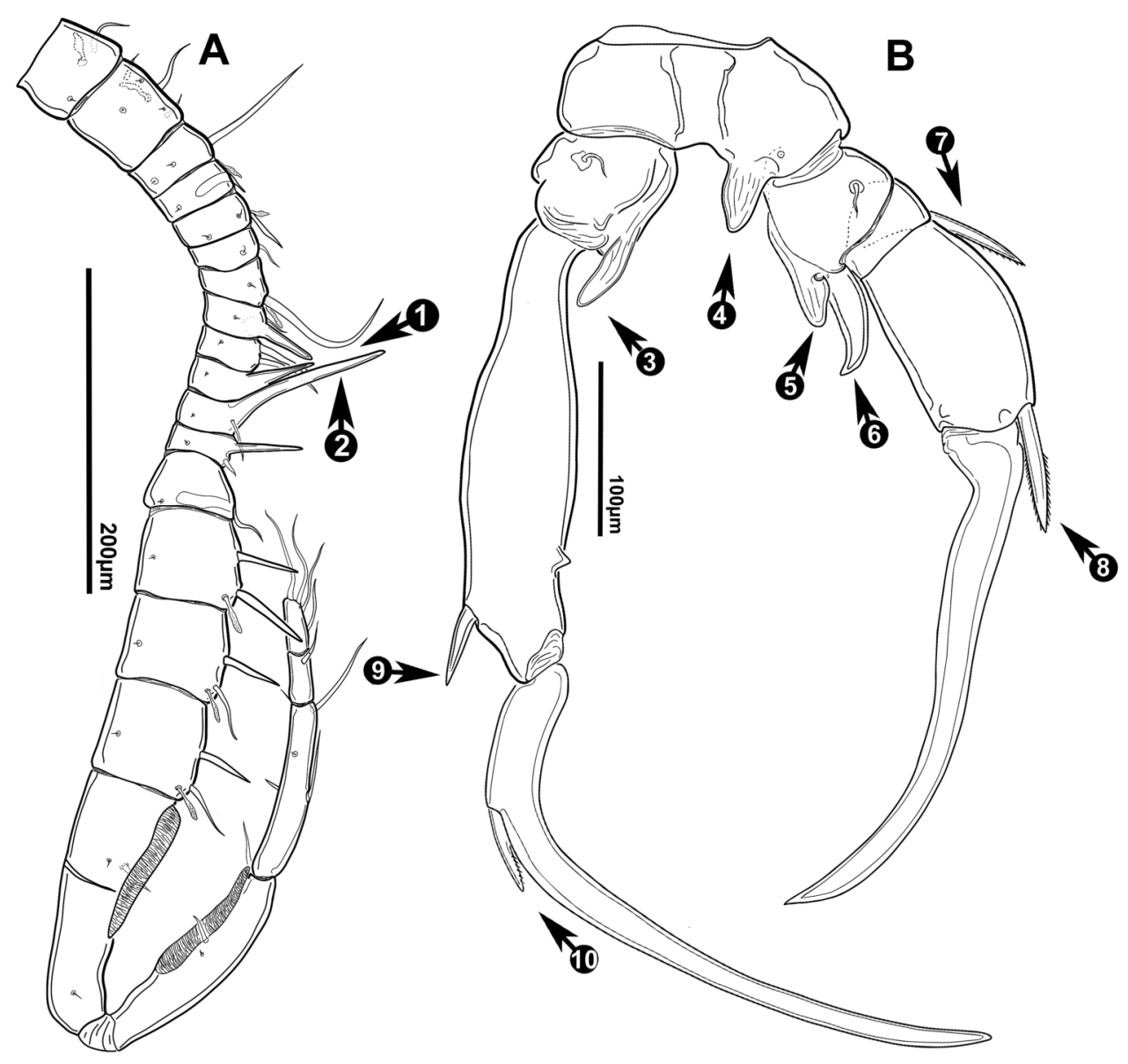

Figure 2. A. Drawings of dissections of male specimens of Boeckella bergi found in Santa Catarina. 1: spinous process on segment 10; 2. Spinous process on segment 11 (Scale: $200 \mu \mathrm{m}$ ). B. P5, caudal view (Scale: $100 \mu \mathrm{m})$; 3: left endopodite, 4: inner process on right coxopodite, 5: inner process on right basipodite, 6: right endopodite, 7 spine on right exopodite 1, 8: spine on right exopodite 2, 9: spine on left exopodite 1, 10: spine on left terminal claw.

Observations and photographs were taken with a Quanta 200 FEI electron microscope. Maps were built using Quantum GIS (QGIS) software (Nanni et al. 2012). Line drawings were made with the mentioned microscope equipped with camera lucida.

\section{Results}

We add 13 new records of B. bergi for South America, increasing the north most and south most records for its distribution area (Table 1; Figure 1A, B). The northernmost records were made in Brazil, showing that its distribution is more extensive than previously known.

Males of $B$. bergi are recognizable by the peculiar spinous processes in the right antennule and the fifth leg (P5) (Figure 3A). The organisms were identified according to the original description (Richard 1897) and later (1901) more detailed observations of the right geniculate antennule made separately by Mrazek and Daday. The fifth leg shown in our study (Figure 2B) is similar to Figure 2 from Richard (1897). The male right geniculate antennule showed an outstandingly long spinous process at segment 11 (Figure 2A), and also a modified seta at segment 19 (Figure 3C). Females of B. bergi possess posteriorly projected lateral wings at the fifth pediger, the left of which is conspicuously notched on its posterior margin (Figure 3A, B).

\section{Discussion}

Richard (1897) described the male of B. bergi upon material from a pond in the outskirts of Buenos Aires, listing as diagnostic characters: (1) the structure and armature of the fifth legs and (2) the long "hook" on segment 12 of the right antennule. In fact he made a mistake counting the segments, and as both Daday (1901) and Mrazek (1901) pointed out, the longest spinous process on the geniculate right antennule is located upon segment 11, as illustrated on Figure 2A. The female, in its turn, was described later by Mrazek (1901) upon specimens collected in a pond in Buenos Aires related to the Rio de la Plata estuary. He included this species within the new genus Boeckellopsis Mrazek 1901, carefully describing and illustrating both sexes. The distinctive diagnostic character for the female is the notch on the posterior edge of the left thoracic wing. Ignoring Mrazeck's work, Daday (1902) redescribed both sexes using material from a pond next to Santa Cruz River in the Argentinean Patagonia, assigning it to the genus Pseudoboeckella Daday, 1902. Brehm (1937) created a number of subspecies and lately considered it as a new species (Brehm 1954), 
Previattelli, D. et al.

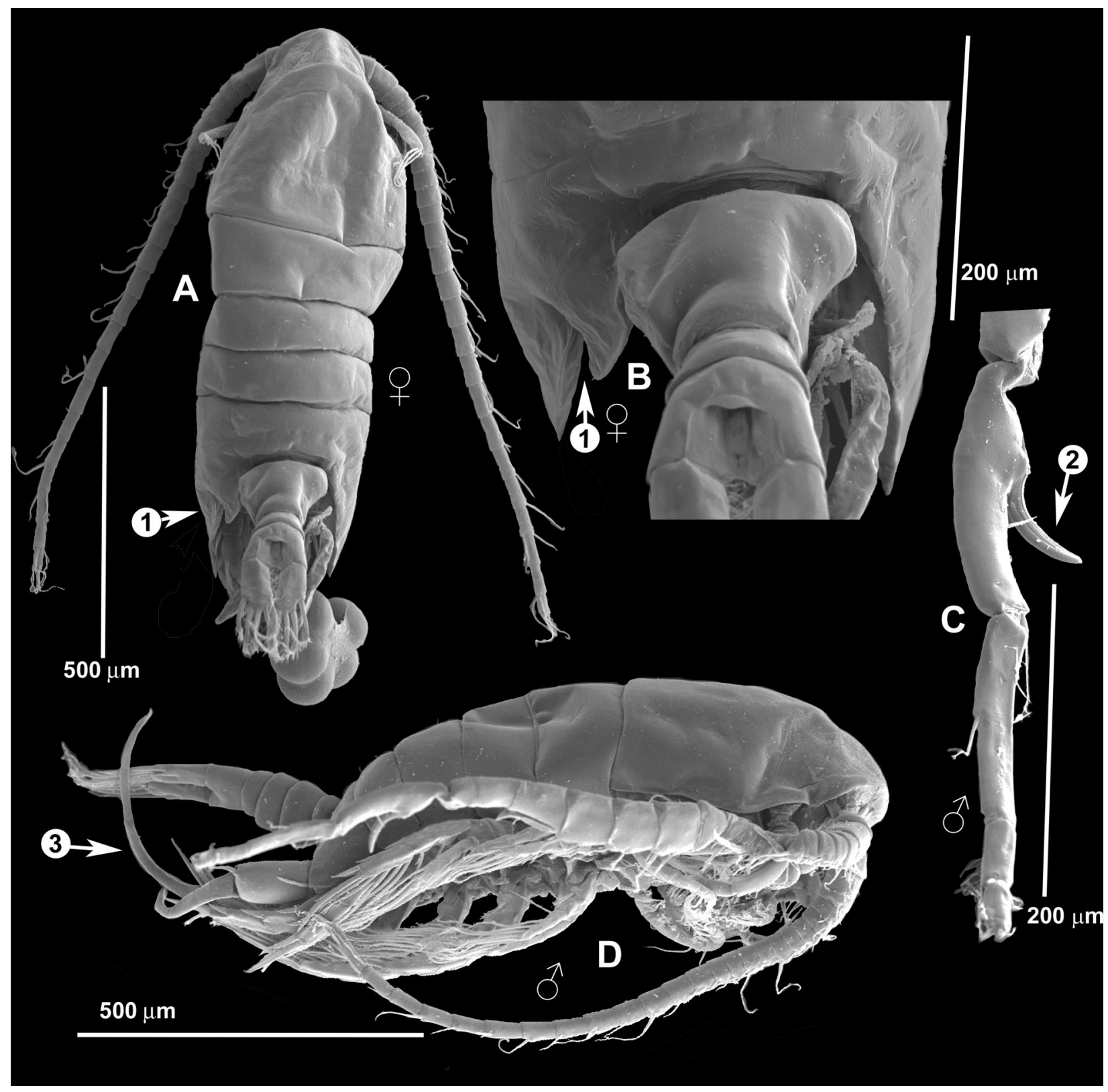

Figure 3. SEM photographs of Boeckella bergi. A and B. Adult female, dorsal view, arrow 1 showing notch on the posterior edge of the left thoracic wing. C. Segments 20, 21 and 22 of right geniculate antennule of male, arrow 2 showing modified seta on segment 19. D. Adult male, right lateral view, arrow 3 showing the terminal claws of the right fifth leg and arrow 4 showing spinous process on segment 20 .

but according to Bayly (1992a) all of these taxa fall within the variability of $B$. bergi.

Concerning the geographic distribution, most of $B$. bergi records have been registered in Argentina (Menu-Marque \& Locascio de Mitrovich 1998; Menu-Marque et al. 2000) and it was also found in small ponds close to the Rio de la Plata estuary on the Uruguayan coast (Brehm 1935, 1937). The presence in a single locality across the Andean range in Chile (Menu-Marque et al. 2000) may be assigned to fish stocking into Laguna de Aculeo where Argentinean silverside was introduced in the twentieth century. This species has a wide latitudinal range within Argentina spanning from about $50^{\circ} \mathrm{S}$ in the Patagonian province of Santa Cruz (Daday 1902), spreading across the Pampean plain in the province of Buenos Aires (Ringuelet 1958; Reid 1991; Mrázek 1901; Brian 1925;
Pesta 1927) until $30^{\circ} \mathrm{S}$ in the Paraná River floodplain (Ringuelet 1958; Paggi 1980), and the northernmost record at $28^{\circ} \mathrm{S}$ from this study, at São Joaquim city (Brazil).

Boxshall \& Jaume (2000) hypothesized that the genus invaded South America at least as early as 120 Mya (Aptian, Lower Cretaceous), and probably had a still wider distribution through the continent. According to these authors there is a latitudinal strip in which members of Centropagidae and Diaptomidae families coexist, with a gradual advance of the Diaptomidae southwards. In Argentina there are many waterbodies from $30^{\circ} \mathrm{S}$ in the Paraná River floodplain to the reservoirs of the northern border of Patagonia at almost $39^{\circ} \mathrm{S}$ where species of Boeckella and Notodiaptomus Kiefer 1936 coexist.

This latitudinal overlap of the families Centropagidae and Diaptomidae occurs both in Australia and South America, 
although in Argentina this area is more extended on the account of the wide distribution of $B$. bergi which coexists with diaptomids of the genus Notodiaptomus in the Rio de La Plata and its tributaries, many shallow lakes in the province of Buenos Aires and an artificial lake connected to the Negro River in northern Patagonia. Boeckella gracilipes Daday 1901 also coexists with Notodiaptomus incompositus (Brian 1925) in a large reservoir on the Limay River (Puig 1991). A similar coexistence was observed here, with Argyrodiaptomus bergi (Richard 1897) being found together with B. bergi in the pool from São Joaquim (Perbiche-Neves et al. 2011).

Many shallow lakes in the pampean plain used to have populations both of $N$. incompositus and Boeckella gracilis (Daday 1902), as reported by Ringuelet (1958). Although diaptomids were dominant, about twenty years from now $B$. gracilis populations have dwindled (SMM personal observation) to the point of disappearance in these water bodies (lagunas de Chascomús, La Brava, de los Padres, Monasterio), which seems to confirm Boxshall \& Jaume's (2000) hypothesis in high latitudes.

With the new records at Santa Catarina State the distribution of the species is extended $600 \mathrm{~km}$ further north than its previous known range. Thus its latitudinal span is very wide, ranging from almost $28^{\circ} \mathrm{S}$ to over $50^{\circ} \mathrm{S}$ across southern South America. In spite of the extensive samplings, this species was never found in Tierra del Fuego. Possibly these new locations represent the northern distribution limit for both species in Brazil and temperature could be determinant for their occurrence. In Brazil, the only previous record was made by Gloeden (1994) at Lagoa Mirim.

This is the only South American species of the genus that has adapted to running waters. Many of the localities in which it has been collected in Argentina are streams, remnant ponds in river beds, reservoirs with short permanence time of the water, and shallow lakes that have strong currents during the rainy season. It is also the only member of the Centropagidae found in the Paraná River and in the freshwater section of the Rio de La Plata.

\section{Acknowledgements}

To Mr. Tiago Tardivo ("Centro de Microscopia Eletrônica CME - IB" of UNESP-Botucatu) for helping us in the acquisition of SEM pictures, and to Professor Edinaldo Nelson dos Santos Silva (INPA) and to anonymous referees by their valuable suggestions.

\section{References}

BAYLY, I.A.E. 1992a. Fusion of the genera Boeckella and Pseudoboeckella (Copepoda) and revision of their species from South America and sub-Antarctic islands. Revista Chilena de Historia Natural 65:17-63.

BAYLY, I.A.E. 1992b. The non-marine Centropagidae (Copepoda: Calanoida) of the world. The Hague: SPB Academic Publishing, 30p.

BAYLY, I.A.E. \& BURTON, R.H. 1993. Beaver Lake, Greater Antarctica, and its population of Boeckella poppei (Mrazek) (Copepoda: Calanoida). Verhandlungen der Internationalen Vereinigung für theoretische und angewandte Limnologie 25:975-978.

BOXSHALL, G.A. \& HALSEY, S.H. 2004. Introduction to Copepod diversity, Vol. 1. Ray Society Series, No. 166. The Ray Society, London, 966p.

BOXSHALL, G.A. \& JAUME, D. 2000. Making Waves: The Repeated Colonization of Fresh Water by Copepod Crustaceans.
Advances in Ecological Research. 31:61-79, http://dx.doi.org/ 10.1016/S0065-2504(00)31007-8

BREHM, V. 1935. Über die Süsswassserfauna von Uruguay. Archiv für Hydrobiologie 28:295-309.

BREHM, V. 1936. Über die tiergeographischen Verhaltnisse der circumantarktischen Süsswasserfauna. Biological Reviews 11:477-493, http://dx.doi.org/10.1111/brv.1936.11.issue-4

BREHM, V. 1937. Weitere Mitteilungen über die Süsswasserfauna von Uruguay. II Teil. Zur Variabilität der Boeckella bergi Rich. Zoologischer Anzeiger 120:301-306.

BREHM, V. 1954. Sobre los copépodos hallados por el profesor Birabén en la Argentina. (Crustacea). 1a. Comunicación. Neotropica $1: 37-42$.

BRIAN, A. 1925. Di alcuni Copepodi d'acqua dolce dell'Argentina raccolti dal Prof. F. Silvestri. Memorie della Societá Entomologica Italiana 4(6): 177-200.

DADAY, E. 1902. Mikroskopische Süsswassertiere aus Patagonien, gesammelt von Dr. Filippo Silvestri in Jahre 1889-1900. Thermészetrajzu Füzetek 25:201-310.

EKMAN, S. 1905. Cladoceren und Copepoden aus antarktischen und subantarktischen Binnengewässern, gesammelt von der schwedischen antarktischen Expedition 1901-1903. Wissenschaftliche Ergebnisse der Schwedischen Südpolar-Expedition 1901-1903. Zool 5(3):1-40.

FELGENHAUER, B.E. 1987. Techniques for preparing crustaceans for scanning electron microscopy. Journal of Crustacean Biology 7:71-76, http://dx.doi.org/10.2307/1548626

GLOEDEN, I.M. 1994. Ocorrência de Boeckella bergi Richard, 1897 (Copepoda, Calanoida) na Lagoa Mirim, Rio Grande do Sul, Brasil. Nauplius 2:123-124.

HARDING, J.P. 1941. Lower Crustacea. Scientific Reports of the British Graham Land Expedition 1934-1937 1:319-322.

HEYWOOD, R.B. 1977. A limnological survey of the Ablation Point area, Alexander Island, Antarctica. Philosophical Transactions of the Royal Society of London (series B) 279:39-54.

HUYS, R. \& BOXSHALL, G.A. 1991. Copepod evolution. I. London: The Ray Society, 468p.

JANIEC, K. 1988. Pseudoboeckella poppei (Copepoda, Calanoida) from Petrel Lake in Antarctic Penguin Island. Polish Archives of Hydrobiology 35:181-184.

MENU-MARQUE, S. \& LOCASCIO DE MITROVICH, C. 1998. Distribución geográfica de las especies del género Boeckella (Copepoda, Calanoida, Centropagidae) en la República Argentina. Physis, Buenos Aires, Sección B, Las Aguas Continentales y sus Organismos 56:1-10.

MENU-MARQUE, S., MORRONE, J.J. \& LOCASCIO DE MITROVICH, C. 2000. Distributional patterns of the South American species of Boeckella (Copepoda: Centropagidae): a track analysis. Journal of Crustacean Biology 20(2):262-272, http://dx. doi.org/10.1163/20021975-99990038

MORRONE, J.J. 2004. La zona de transición sudamericana: caracterización y relevancia evolutiva. Acta Entomológica Chilena 28(1):41-50.

MRAZEK, A. 1901. Süsswasser-Copepoden. Ergebnisse der Hamburger Magalhänsischen Sammelreise 6(2):1-29.

NANNI, A.S., DESCOVI FILHO, L., VIRTUOSO, M.A., MONTENEGRO, D., WILLRICH, G., MACHADO, P.H., SPERB, R., DANTAS, G.S. \& CALAZANS, Y. 2012. Quantum GIS Geographic Information System. Open Source Geospatial Foundation Project. Available online at: http://qgis.osgeo.org. [Accessed: 03 July 2013].

PAGGI, J.C. 1983. Estudios limnológicos en la Península Potter, Isla 25 de Mayo, (Shetland del Sur, Antártida): morfología y taxonomía de Pseudoboeckella poppei Mrázek 1901, (Crustacea, Copepoda). Contribuciones Científicas del Instituto Antártico Argentino 303:1-34.

PESTA, O. 1927. Ein Beitrag zur Kenntnis der Copepodenfauna von Argentinien. Zoologischer Anzeiger 73:67-80. 
PERBICHE-NEVES, G., PREVIATTELLI, D. \& NOGUEIRA, M.G. 2011. Record of Argyrodiaptomus bergi (Crustacea: Copepoda: Calanoida) after 36 years and first record in Brazil. Zoologia 28(5):551-557, http://dx.doi.org/10.1590/S1984-46702011000500001

PEZZANI-HERNÁNDEZ, S. 1973. Descripción de adultos y estadios inmaduros en Pseudoboeckella poppei Mrázek, 1901 (Copepoda Calanoida). Importancia de su morfología externa en la taxonomía y en sus hábitos alimentarios. Instituto Antártico Chileno, Serie Científica 3:28-44.

POPPE S.A. \& MRÁZEK, A. 1895. Entomostraken des Naturhistorischen Museum in Hamburg. 2. Entomostraken von Süd-Georgien, 2. Jahrbuch. Hamburgischen Wissenschaftlichen Anstalten 12:135-138.

PUIG, A. 1991. Densidad y estructura comunitaria de crustáceos planctónicos en el embalse E.R. Mexía (Patagonia, Argentina). Biología Acuática 15:132-133.
REID, J.W. 1991. The Stillman Wright collection of Copepoda (Crustacea) from South America in the National Museum of Natural History, Smithsonian Institution. Proceedings of the Biological Society of Washington 104(4):736-741.

RICHARD, J. 1897. Sur quelques entomostracés d'eau douce des environs de Buenos Aires. Anales del Museo Nacional de Historia Natural de Buenos Aires 5:321-331.

RINGUELET, R.A. 1958. Los Crustáceos Copépodos de las aguas continentales de la República Argentina. Sinopsis sistemática. Contribuciones científicas de la Facultad de Ciencias exactas físicas y naturales, Universidad de Buenos Aires, Zoología 1:35-126.

WELLER, D.L.M. 1977. Observations on the diet and development of Pseudoboeckella poppei (Calanoida, Centropagidae) from an Antarctic lake. British Antarctic Survey Bulletin 45:77-92.

Received 06/06/2014

Revised 28/05/2015

Accepted 17/07/2015 